\title{
Humanitarian technology: a critical research agenda
}

\section{Kristin Bergtora Sandvik, Maria Gabrielsen Jumbert, John Karlsrud and Mareile Kaufmann*}

Kristin Bergtora Sandvik, S.J.D. Harvard Law School, is a Senior Researcher at the Peace Research Institute Oslo (PRIO) and the Director of the Norwegian Centre for Humanitarian Studies. Her research takes a socio-legal approach to technology, international law and humanitarian action. Her work has appeared in, inter alia, Disasters; the International Journal of Refugee Law; Refugee Survey Quarterly; Millennium: Journal of International Studies; and the IFRC World Disasters Report 2013.

Maria Gabrielsen Jumbert, PhD, is Senior Researcher at PRIO, working on issues related to humanitarianism, surveillance technologies and international responses to crises. Her work has appeared in, inter alia, the Journal of Modern African Studies, Third World Quarterly and the Human Security Journal. John Karlsrud, $\mathrm{PhD}$, is Senior Research Fellow at the Norwegian Institute of International Affairs (NUPI) working on peacekeeping, peacebuilding and humanitarian issues. His work has appeared in, inter alia, Conflict, Security and Development; Disasters; Global Governance; and Global Responsibility to Protect.

* This article is based on the 2013 Critical Humanitarian Technology Projects undertaken by PRIO and the Norwegian Center for Humanitarian Studies. The Research has been funded in part by the Training for Peace programme at the Norwegian Institute of International Affairs. We are grateful to the anonymous reviewers, Vincent Bernard and the ICRC, the Norwegian Red Cross, Patrick Meier, Daniel Gilman, Ryan Burns, Christopher Wilson, Michael Kleinman, Anahi Iaccuci and Nathaniel Raymond. Errors and omissions remain our own. 
Mareile Kaufmann is a doctoral student at PRIO and Hamburg University. She works on security issues in interconnected, technologized and digitalized societies with a special focus on resilience and crisis management. Her work has appeared in Resilience and Internasjonal Politikk.

\section{Abstract}

New technology may offer many opportunities for humanitarian action, but it also presents a number of challenges. Currently, most of the critical analysis of these potential challenges takes place in the blogosphere, on tweets and on listservs. There is a strong need for more scholarly engagement on the subject. This article offers an agenda for critical inquiry into the emergent field of humanitarian technology as applied to a broadly defined context of crises, encompassing both natural disasters and conflict zones, by identifying what technology does to the humanitarian enterprise, and by reflecting on the key challenges that emerge.

Keywords: humanitarian technology, humanitarian innovation, humanitarian principles, cash cards, digital food, crisis mapping, crowdsourcing, big data, science and technology studies.

The humanitarian enterprise is characterized by considerable optimism regarding the possibility of improving humanitarian action through new, digital technology. ${ }^{1}$ The uses of mobile phones, social media platforms, geospatial technologies and various forms of crowdsourcing have fundamentally altered how humanitarian crises are detected and addressed, and how information is collected, analysed, and disseminated. Biometric identification technologies are increasingly used as tools for emergency support and refugee management. Relief provision is beginning to shift towards virtual distributions through digital payment systems, so-called e-transfers or "mobile money." There are significant expectations surrounding the humanitarian uses of drones. As broadly acknowledged by policymakers and a burgeoning field of scholarly contributions, these developments are changing the possibilities for prevention, response and resource mobilization for humanitarian actors and affected communities alike.

The 2010 Haiti earthquake is commonly seen as the game changer in the chronicles of humanitarian technology. Since then, the institutional and operational focus has been on leveraging technology to enhance humanitarian action, ensuring that more formal relationships are established, and improving the interaction between formal humanitarian organizations such as the United Nations (UN) Office for the Coordination of Humanitarian Affairs (OCHA) and

1 Acknowledging that the notion of technology is very broad and that humanitarian action has always been facilitated by some kind of technology - even as basic as pen and paper - we focus in this article on the influence of novel, mostly digital and web-based information and communication technologies on the humanitarian enterprise. 
informal volunteer and technological communities. ${ }^{2}$ The World Disasters Report 2013 by the International Federation of Red Cross and Red Crescent Societies (IFRC), entitled Focus on Technology and the Future of Humanitarian Action, and the OCHA report Humanitarianism in the Network Age (HINA), have contributed to framing these developments as policy issues. Transformation through technological innovation will also be a key theme at the 2016 World Humanitarian Summit. Yet, despite the great potential and many positive effects of technological innovation, it can also compromise the core principles of humanitarian action and obscure issues of accountability of humanitarian actors towards beneficiaries. The question of how technological innovation affects humanitarian action is in need of more critical enquiry. This article offers an agenda for future research on the emergent field of humanitarian technology as applied in a broadly defined context of crisis, encompassing both natural disasters and conflict zones, by identifying what technology does to the humanitarian enterprise, and by reflecting on the key challenges that emerge. Just as man-made or natural disasters present different types of challenges to humanitarian action in general, they may also present different types of challenges in the application of new technologies. We are aware of this, but seek to highlight in this article some of the general challenges that may arise, in order to stake out avenues for future research.

From a scholarly perspective, this is a fast-moving and immature field. There has been an avalanche of "tech-optimistic" scholarly work, premised on the belief that adding technology will change things for the better. ${ }^{3}$ Scholars have given attention to the opportunities that new technologies offer for making humanitarian action more effective, and their potential for strengthening local ownership. It is generally acknowledged that it is not helpful to do gap studies, such as assessments of discrepancies between policy and technical standards on the one hand, and implementation on the other (possibly due to the speed of innovation and local re-contextualization), nor to take a Luddite view of the technology (it is not going away). Somewhat unusually, but in tandem with the nature of the subject matter, most critical and theoretical contributions can be found in exchanges in the blogosphere, on tweets and on listservs. ${ }^{4}$ As observed by Ryan Burns, in order to demonstrate its value to intended audiences, the field of digital humanitarianism is actively - if not explicitly - negotiating its

2 Patrick Meier, "New Information Technologies and Their Impact on the Humanitarian Sector", International Review of the Red Cross, Vol. 93, No. 884, 2011, pp. 1239-1263.

3 See e.g. Harvard Humanitarian Initiative, Disaster Relief 2.0: The Future of Information Sharing in Humanitarian Emergencies, UN Foundation and Vodafone Foundation Technology Partnership, Washington DC and Berkshire, 2011; Francesco Mancini (ed.), New Technology and the Prevention of Violence and Conflict, International Peace Institute, New York, April 2013.

4 See, for example, Patrick Meier's blog, available at: http://irevolution.net/; the Wilson Centre's Science and Technology Innovation Program blog, available at: wilsoncommonslab.org; the Advanced Training on Humanitarian Action blog, available at: http://atha.se/; The Diary of a Crisis Mapper blog, available at: http://crisismapper.wordpress.com/; and the Global Humanitarian Technology Conference, accessible through the following email address: GHTC-CONTACTS@LISTSERV.IEEE.ORG. 
own knowledge politics, through a privileged position from which it can leverage competence and authority on data and technology. ${ }^{5}$

At the same time, there is so far limited critical scholarly engagement with the humanitarian turn to technology. We suggest that this is problematic for several reasons: firstly, as most technologies enable the collection and analysis of data, it needs to be pointed out that algorithms have politics; they are neither neutral nor natural, and there is a need to bring political contestation to the fore. ${ }^{6}$ Another issue concerns the physical presence of technology in the humanitarian setting: the humanitarian community perceives the greatest challenge to be the creation of actionable and credible information that may be quickly transmitted to, and understood by, vulnerable communities. When humanitarian actors discuss possible negative outcomes, these are usually addressed through the recommendation of incremental improvements, along the lines of "We can do this (more) ethically if we can get more organized, have better equipment, or develop clearer standards." Yet such "improvements" engender their own dynamics: technology mediates and alters human relationships and understandings of protection. The turn to technology also changes perceptions of what aid is, and what it means to provide it, as reflected in the often-repeated assertions that "humanitarian information is humanitarian aid" or "information is a basic need." Moreover, there is a significant but little understood political economy aspect to the rise of humanitarian technology: both the military industry and the surveillance industry are looking for new markets and the type of legitimacy that partnership with a humanitarian actor can provide.

Mark Duffield argues that, rather than uncritically embracing "cyberhumanitarianism", humanitarian agencies need to understand exactly what they are buying into. ${ }^{7}$ Taking such calls for a critical investigation of technology as a vantage point, the objective of this article is to offer a set of substantive pointers for a critical humanitarian technology research agenda. To that end, we are moving from a discussion of what technology does for humanitarian action to asking what technology does to humanitarian action. We identify humanitarian space, the generation of new partnerships, shifts in resource distribution, transformations of human relationships and the emergence of new vulnerabilities as analytical prisms for exploring this question. Our goal is to analyze and highlight how critical approaches to technology can inform a more reflective humanitarian practice, enhancing the humanitarian community's ability to grapple with the ongoing transformation of the humanitarian enterprise and its

5 Ryan Burns, "Moments of Closure in the Knowledge Politics of Digital Humanitarianism", Geoforum, Vol. 53, 2014, pp. 51-62.

6 Gus Hosein, personal communication, the Critical Humanitarian Technology Project Seminar, PRIO, 28 November 2013; similarly discussed in critical security studies, e.g. in Louise Amoore, "Algorithmic War: Everyday Geographies on the War on Terror", Antipode, Vol. 41, No. 1, 2009, pp. 49-69.

7 Mark Duffield, "Disaster-Resilience in the Network Age: Access-Denial and the Rise of CyberHumanitarianism”, DIIS Working Paper No. 23, 2013, available at: http://en.diis.dk/files/publications/ WP2013/WP2013-33_Disaster-resilience-cyber-age_Duffield_web.pdf. 
operations, through and by technology. The approach is exploratory and built on secondary sources, unless otherwise indicated.

For the purposes of clarity, the topical focus of this article is on a specific slice of the humanitarian technology field, namely humanitarian information and communication technologies (mirroring the priorities of the IFRC World Disasters Report); it thus leaves aside other technologies such as biometrics and humanitarian drones. ${ }^{8}$ Mobile phones, social media, crisis mapping, big-data analytics and e-transfers are all tools that can give beneficiaries the opportunity to take informed decisions in a crisis, give humanitarians better situational awareness and improve aid delivery. We are interested in the particular social interactions and practices these technologies allow for. How does technology create or reshape humanitarian space, power relationships and relief distribution? How can we make sense of the new possibilities for remoteness that technology brings to humanitarian action?

The article is divided into two main parts. The first part starts by providing a description of the hardware and software aspects of the relevant technologies, and the capabilities they are expected to bring to the field of humanitarian action. It then examines humanitarian technology as a theoretical idea, focusing on the constitutive relationship between technology and humanitarianism. The second part considers some of the ways in which technology brings changes to the humanitarian field. The discussion is organized into five sections, covering the relationship between technology and the contested issue of humanitarian space; the generation of new settlements in terms of generating a new shared understanding of meaning, roles, resource distribution and rules, such as the growth of public-private partnerships; the production of new forms of distribution of resources, namely through e-transfers or so-called "digital food"; the reorganization of the relationships between the "helper" and the "helped"; and finally the continuous manufacturing of new vulnerabilities engendered by data collection and processing. In the conclusion, we consider the implications for the "do no harm" imperative and the humanitarian principles of humanity, impartiality and neutrality. ${ }^{9}$ We look at how humanitarian action, as it has evolved from the Red Cross Movement, is based on the imperative to "do no harm" in the pure medical sense, but also in the broader sense of acknowledging the impact one has when intervening in a situation of crisis. ${ }^{10}$ We reflect on how technologies introduced in the humanitarian field relate to this imperative, how they affect the everyday achievement of humanitarian principles and how they alter practices in the field.

8 For a discussion, see Kristin Bergtora Sandvik and Kjersti Lohne, "The Rise of the Humanitarian Drone", Millennium Journal of International Studies, Vol. 43, No. 1, 2014. See also Kristin Bergtora Sandvik and Maria Gabrielsen Jumbert (eds), The Good Drone, Ashgate, Surrey, forthcoming 2015.

9 Encoded in the Statutes of the Red Cross and Red Crescent movements, and encoded in various UN General Assembly resolutions, notably UN GA Res. 46/182, 19 December 1991.

10 Mary B. Anderson, Do No Harm: How Aid Can Support Peace or War, Lynne Rienner, Boulder CO, 1999. 


\section{Technology in crisis situations: towards an idea of humanitarian technology}

The world has entered the age of "big data." Data is gathered and generated at an exponential rate, doubling every 20th month: in 2012, the volume of digital content grew to 2.7 zettabytes (ZB), up $48 \%$ from $2011 .{ }^{11}$ This is a function of a general digitalization of our lives, since many ordinary actions in everyday life can now be traced, stored and shared. The trend is no longer limited to the Western world. An increasing portion of the population in the South, including countries ravaged by war and conflict, is also stepping into the digital realm. This means that the amount of data that can be analysed to inform multilateral efforts for conflict prevention and international security is increasing rapidly and can thus give a more even and realistic picture of the situation in question.

Even in fragile countries, many people have a cell phone. And while cell phone ownership is not universal and most cell phones are not smartphones, there is a rapid spread of $3 \mathrm{G}$ networks in developing countries and smartphones are increasingly affordable as they are priced down to US\$40 or less. ${ }^{12}$ Cell phone usage enables remote communication, data transfers and establishment of management procedures, and has the potential to be hugely helpful with respect to preparedness, response and recovery. Examples include mitigation of the harmful effects of a crisis by way of providing early warning through text messaging, or real-time evaluations through SMS feedback from affected people receiving aid. As the trend towards digitalization of money has reached crisis and disaster zones, material relief is now increasingly distributed through e-transfers or by SMS.

The data that populations generate through their everyday actions can be correlated to other information through crowdsourcing, identifying patterns of resource flows, movement and consumption. Crowdsourcing is a blanket term covering an array of ways in which many people contribute small amounts of data to form an aggregated larger dataset, usually via electronic means. In an aggregated form, such data can provide important insights into humanitarian needs and the effectiveness of interventions. Many types of data can be collected and aggregated to give a real-time understanding of developments in a particular area. Tracking the use of hate speech on social media can highlight areas of increased tension and potential violence. A sudden growth in remittances to particular countries or geographical locations can be a sign of greater vulnerability. Cell phone data can be used to track population movements in case of violent clashes or natural disasters. ${ }^{13}$ SMS surveys can be conducted in

11 Business Wire, "IDC Predicts 2012 Will Be the Year of Mobile and Cloud Platform Wars as IT Vendors Vie for Leadership While the Industry Redefines Itself”, 1 December 2011, available at: www.businesswire. com/news/home/20111201005201/en/IDC-Predicts-2012-Year-Mobile-Cloud-Platform\#.U4uByi-kEy4.

12 Gulveen Aulakh, "Smartphone Rates May Slip Below 2.5k by Year-End", Economic Times, 19 March 2014, available at: http://articles.economictimes.indiatimes.com/2014-03-19/news/48366178_1_smartphoneshandset-makers-karbonn-mobiles.

13 Linus Bengtsson et al. "Improved Response to Disasters and Outbreaks by Tracking Population Movements with Mobile Phone Network Data: A Post-Earthquake Geospatial Study in Haiti”, PLoS 
cooperation with cell phone companies to generate input on food insecurity or fear of violence. During disastrous events, data about the situation of disaster victims from various information sources, such as texts, e-mails, blog posts and tweets, can be processed by crisis mappers in order to create layered maps with georeferenced information, thus allowing for the detection of focal points that are not easily identified through other technologies. ${ }^{14}$

A critical research agenda in this field raises the question of the academic tools and concepts we use to think about humanitarian technology. As noted by Duffield, there is a need to contemplate how technology and humanitarian policies on the ground change together, meaning that work in disciplines such as anthropology, sociology and geography, as well as history and cultural studies, will be important - in tandem with a thorough theorization. ${ }^{15}$ We suggest that while there has until now been little critical investigation into the use of new technology in humanitarian assistance, humanitarian studies being in itself a field in the making, a research agenda for the study of humanitarian technologies can learn a lot from science and technology studies (STS). With its critical view on technologies and their social functionalities, STS has significantly contributed to the understanding of what new technologies do to both social and power relationships. ${ }^{16}$ Today, throughout the humanitarian field, technology enables specific sets of political and military rationales and projects that must be examined not for their oft-alleged "newness", but for the power they represent. ${ }^{17}$ The question is: where is power found, what does it look like, and how does it operate?

In our view, there has never been any humanitarianism without technology. ${ }^{18}$ Furthermore, technology is not "bad" - but neither is it neutral, or just passively adopted by society. Technology is not an empty vessel waiting to be imbued with "humanitarian meaning"; rather, society and technology engage in a mutually constitutive relationship. ${ }^{19}$ The construction of technology is subject to political contestation, and to the realities of professionalism and finance. ${ }^{20}$

Med, No. 8, Vol. 8, 2011; UN Global Pulse, Characterizing Human Behavior During Floods Through the Lens of Mobile Phone Activity, 2014, available at: www.unglobalpulse.org/tabasco-floods-CDRs.

14 Anne Nelson and Ivan Sigal with Dean Zambrano, "Media, Information Systems and Communities: Lessons From Haiti", (published 21 January 2011), available at: www.knightfoundation.org/media/ uploads/publication_pdfs/KF_Haiti_Report_English.pdf.

15 Mark Duffield, personal communication; Critical Humanitarian Technology Seminar, PRIO, 28 November 2014.

16 Wiebe E. Bijker and John Law, Shaping Technology/Building Society: Studies in Socio-Technical Change, MIT Press, Cambridge MA, 1992; Donald MacKenzie and Judy Wajcman, The Social Shaping of Technology, Open University Press, Milton Keynes, 1999; Geoffrey L. Herrera, "Technology and International Systems", Millennium: Journal of International Studies, Vol. 32, No. 3, 2003, pp. 559-593; Stefan Fritsch, "Technology and Global Affairs", International Studies Perspectives, Vol. 12, No. 1, 2011, pp. 27-45; Daniel R. McCarthy, “Technology and 'the International' or: How I Learned to Stop Worrying and Love Determinism”, Millennium: Journal of International Studies, Vol. 41, No. 3, 2013, pp. $470-490$.

17 D. R. McCarthy, above note 16, pp. 471 and 489.

18 Scholars have long been interested in the use of technology for humanitarian purposes: see Robin Stephenson and Peter S. Anderson, "Disasters and the Information Technology Revolution", Disasters, Vol. 21, No. 4, 1997, pp. 305-334.

19 D. MacKenzie and J.Wajcman, above note 16.

20 G. L. Herrera, above note 16, p. 560; see also W. E. Bijker and J. Law, above note 16. 
According to Patrick Vinck, humanitarian technology refers to the use of technology to improve the quality of prevention, mitigation, preparedness, response, recovery and rebuilding efforts. ${ }^{21}$ Acknowledging the support functions that humanitarian technology can fulfil, but also pointing to the potential challenges of technological application, we suggest that humanitarian technology is both constituted by and constitutive of humanitarian practice. Humanitarian technology should be understood in the context of ideas about functionality and effectiveness - or perceptions about vulnerability and suffering - underpinning the contemporary humanitarian agenda. ${ }^{22} \mathrm{New}$ communication technologies are bounded in relation to other kinds of technology, and in relation to social and cultural sentiments about the "appropriateness" of particular tools and practices. These relations in turn infuse the mundane, everyday practices underpinning the adoption and use of "new" technologies. ${ }^{23}$

This perspective is particularly significant for an understanding of the Internet's role within the global emergency zone, as well as in society at large. With social media, the long-held notion that the virtual world is a different social space to the "real world" has mostly given way to the understanding that there is one social world, which contains both traditional and technologically advanced modes of communication and sites of social activity. ${ }^{24}$ Early optimism about the emancipatory potential of social media in the Arab Spring has been countered by negative conceptualizations of the Internet as a tool of propaganda used by armed actors and oppressive governments, as epitomized by Syria. This article adopts the view that a dichotomy between liberation and control is misleading: technologies - including humanitarian information and communication technologies - in turn shape and limit the prospects for human communication and interaction in a constantly iterative manner. ${ }^{25}$

\section{Humanitarian technology: understanding changes and challenges}

\section{Technology and the politics of the humanitarian space}

The following five sections will outline a critical agenda by investigating the impact that the use of technology has on humanitarian space. They will discuss the way in

21 Patrick Vinck, "Humanitarian Technology", World Disasters Report 2013, International Federation of Red Cross and Red Crescent Societies, 2013, p. 20, available at: www.ifrc.org/PageFiles/134658/WDR\% 202013\%20complete.pdf.

22 Because of space constraints, the ways in which humanitarianism shapes technology - for example, by providing "doing good" legitimacy - will not be discussed further here.

23 Marianne De Laet and Annemarie Mol, "The Zimbabwe Bush Pump: Mechanics of a Fluid Technology", Social Studies of Science, Vol. 30, No. 2, 2000, pp. 225-263.

24 Angela Cora Garcia et al., "Ethnographic Approaches to the Internet and Computer-Mediated Communication", Journal of Contemporary Ethnography, Vol. 38, No. 1, 2009, pp. 52-84.

25 Ronald Deibert and Rafal Rohozinski, "Liberation vs. Control: The Future of Cyberspace", Journal of Democracy, Vol. 21, No. 4, 2010, pp. 43-56. 
which technology creates new settlements with respect to how humanitarian work can legitimately be organized, the effect of technology on the distribution of resources, the way in which technology is redefining relationships, and the way in which data collection creates new vulnerabilities.

Discussions about the use of humanitarian technology inevitably fold into the long-term debate about "humanitarian space", a concept that remains central to humanitarian policymaking. ${ }^{26}$ While the technical definitions of this concept vary, a common conception of humanitarian space is the ability of agencies to operate freely and meet humanitarian needs in accordance with the principles of humanitarian action. ${ }^{27}$ Over the past decade, as the international community has grappled with the protection of civilians and relief provision in Afghanistan, the Democratic Republic of the Congo, Darfur, Iraq, Sri Lanka, and most recently South Sudan and Syria, there has been a persistent concern that the space for humanitarian action is shrinking. This is perceived to result both in less access to crisis settings - with serious consequences for beneficiaries - and a more dangerous operative environment for humanitarian workers. ${ }^{28}$ The idea of a shrinking humanitarian space directly influences views on the role of technology within such settings. Technology is here mainly perceived as an instrument to allow for remote management of hard-to-reach areas, for example through the use of SMS surveys to map basic needs, or reliance on Skype for day-to-day management. Technology is thus mainly framed in terms of its instrumentality to maintaining humanitarian access. While this instrumentalist perspective needs to be critically investigated, it is useful to illuminate a practical challenge: humanitarian actors operate in environments that are intrinsically dynamic and unstable and that diverge from the typical environment in which technology is designed, such as the private sector. ${ }^{29}$ In the emergency context, the failure rates of sophisticated technologies are likely to be high. ${ }^{30}$ Design and manufacturing defects, human error and human-machine interface problems will shape their implementation, even with appropriate planning.

Instead of conceptualizing the humanitarian space as one that is shrinking, but can be saved by technological means, we suggest that the humanitarian space could be understood as a social arena where various actors (donors, UN agencies, NGOs, staff, beneficiaries, private sector actors, peacekeepers and other military

26 This section builds on Kristin Bergtora Sandvik, "The Humanitarian Cyber Space: Expanding Frontiers or Shrinking Space?", 2014, unpublished manuscript on file with the author.

27 Victoria Metcalfe, Alison Giffen and Samir Elhawary, UN Integration and Humanitarian Space, Overseas Development Institute, London, 2011; Sarah Collinson, Samir Elhawary, "Humanitarian Space: A Review of Trends and Issues", HPG Reports, No. 32, Overseas Development Institute, London, 2012.

28 Humanitarian Outcomes, Aid Worker Security Report 2013: The New Normal: Coping with the Kidnapping Threat, October 2013, available at: www.humanitarianoutcomes.org/sites/default/files/ HO_AidWorkerSectyReport_2013_0.pdf.

29 IFRC, World Disasters Report 2013, Chapter 7: "Innovation, Evaluation and Diffusion of Humanitarian Technology".

30 For examples, see Gus Hosein and Carly Nyst, Aiding Surveillance, Privacy International, October 2013, available at: www.privacyinternational.org/sites/privacyinternational.org/files/file-downloads/aiding surveillance.pdf. 
actors) negotiate activities and outcomes. ${ }^{31}$ In our view, the shrinking-space narrative implicitly builds on the myth of a "Golden Age" of non-political humanitarianism and unfettered humanitarian access. As observed by Antonio Donini, the reality has always been characterized by a gap between the aspiration to a set of ideals and the everyday humanitarian politicking in complex political, military and legal arenas. ${ }^{32}$ Technology-driven humanitarian action only has a limited potential to break free of the pre-existing political constraints that shape humanitarian access. Humanitarian technology may shelter humanitarianism from the politics of danger by protecting the physical security of humanitarian workers, but it will not save humanitarians from dangerous politics, or from politics in general. ${ }^{33}$

For example, technology can simultaneously be a medium of violence and of humanitarian action: historically, the radio has been the most important humanitarian information technology, but at the same time, violent actors have leveraged communication technologies to incite violence, promote conflict and perpetrate crimes. The classic example is the 1994 Rwandan genocide, where the broadcasts of Radio Télévision Libre des Mille Collines played a significant role in inciting mass killings. Moreover, in view of the nature of an emergency setting, any failure to consider the possible secondary effects of applying a specific new technology can lead to fatal outcomes.

With the rise of digital humanitarianism, areas with limited or non-existent access to connectivity and digital technologies - risk becoming an invisible part of the humanitarian space. ${ }^{34}$ As noted by Patrick Vinck, "the on-the-ground reality is more often than not one of information poverty, limited mobile coverage and little or no access to internet for both humanitarians and communities at risk." 35 While one in four people on earth have started using some form of social media regularly, access is deeply unequal across the global emergency zone. ${ }^{36}$ Whereas the digital humanitarian response to Typhoon Yolanda in the Philippines played a significant role-71\% of the population has a cell phone and $34 \%$ a smartphone - the percentage of the population online in 2014 is $12 \%$ in Uganda and $8 \%$ in Pakistan. ${ }^{37}$ In addition to that, there are also geographically gendered

31 Dorothea Hilhorst and Bram J. Jansen, "Humanitarian Space as Arena: A Perspective on the Everyday Politics of Aid", Development and Change, Vol. 41, No. 6, 2010, pp. 1117-1139.

32 Antonio Donini (ed.), The Golden Fleece: Manipulation and Independence in Humanitarian Action, Kumarian Press, Sterling VA, 2012.

33 Kristin Bergtora Sandvik, "The Risks of Technological Innovation", in IFRC, above note 29.

34 For an interesting case of a humanitarian organization addressing its own internal digital divide, see the IFRC's digital divide initiative, "Technology in the Service of the Most Vulnerable", 6 July 2011, available at: www.ifrcmedia.org/blog/technology-in-the-service-of-the-most-vulnerable/.

35 P. Vinck, above note 21, p. 30.

36 eMarketer, "Social Networking Reaches Nearly One in Four Around the World", 18 June 2013, available at: www.emarketer.com/Article/Social-Networking-Reaches-Nearly-One-Four-Around-World/1009976.

37 Pew Research Center, Emerging Nations Embrace Internet, Mobile Technology, 13 February 2014, available at: www.pewglobal.org/2014/02/13/emerging-nations-embrace-internet-mobile-technology/; Neil Dufty, "A Review of the Value of Social Media in Countrywide Disaster Risk Reduction Public Awareness Strategies", paper developed for the HFA Thematic Review and as an input to the Global Assessment Report on Disaster Risk Reduction 2015 (GAR15), available at: http://works.bepress.com/neil_dufty/34. 
differences that create localized digital divides: the technology gap between men and women is much larger in low-income countries than in high-income countries. ${ }^{38}$

While humanitarian actors often emphasize the democratizing potential of information technology in disasters and OCHA proposes that technology redistributes power, ${ }^{39}$ the emphasis on big data comes with its own particular blind spots regarding populations that are overlooked by big data. ${ }^{40}$ Will individuals and communities whose life patterns do not generate enough digital breadcrumbs to make it into the algorithms fall outside the humanitarian space? These are some of the challenges which are important to take into account when assessing the use of technology in the humanitarian setting.

\section{Generating new settlements: the example of public-private partnerships}

The introduction of new technologies and the unprecedented levels of connectivity now being seen across the globe will generate new settlements in the structural division of labour in the humanitarian sector. This changing landscape will involve new actors and the redistribution of tasks and responsibilities, as well as evolving understandings of the legitimacy of giving those new actors important roles in humanitarian action. In this section we will discuss one such important new development-namely, the proliferation of public-private partnerships, which in recent years have emerged as a preferred (and donor-encouraged) humanitarian strategy to reach stated goals of increased efficiency and accountability. ${ }^{41}$ The rationale for including the private sector in humanitarian action is that partners can contribute to humanitarian solutions with different expertise and resources. Besides that, they own much of the infrastructure on which information and communication technology is based. For example, telecom businesses provide text messages, internet and phone services where there is significant potential for harvesting data and where access to "digital exhaust" is emerging as a key concern for humanitarian actors.

These relationships are increasingly being institutionalized. The InterAgency Standing Committee (IASC) Sub-Working Group on Emergency

38 International Telecommunication Union, ICT Facts and Figures: The World in 2013, February 2013, available at: www.itu.int/en/ITU-D/Statistics/Documents/facts/ICTFactsFigures2013-e.pdf; Alison Gillwald, Anne Milek and Christoph Stork, "Gender Assessment of ICT Access and Usage in Africa", Towards Evidence-Based ICT Policy and Regulation, Vol. 1, Policy Paper 2, 2009; Laura L. Murphy and Alexandra E. Priebe, “"My Co-Wife Can Borrow My Mobile Phone!' Gendered Geographies of Cell Phone Usage and Significance for Rural Kenyans", Gender, Technology and Development, Vol. 15, No. 1, 2011, pp. 1-23.

39 OCHA, Humanitarianism in the Network Age (HINA) 2011.

40 Jonas Lerman, "Big Data and its Exclusions", Stanford Law Review Online, 3 September 2013, available at: www.stanfordlawreview.org/online/privacy-and-big-data/big-data-and-its-exclusions.

41 Andrea Binder and Jan Martin Witte, "Business Engagement in Humanitarian Relief: Key Trends and Policy Implications", Humanitarian Policy Group (HPG) Background Paper, Overseas Development Institute (ODI), London, June 2007; Jim Drummond and Nicholas Crawford, "Humanitarian Crises, Emergency Preparedness and Response: The Role of Business and the Private Sector", HPG Report, ODI, London, January 2014. 
Telecommunications, chaired by OCHA, is an open forum to facilitate the operational use of telecommunications in the service of humanitarian assistance, and has been meeting since $1994 .{ }^{42}$ The emergency telecommunications cluster under the UN cluster system was created in 2005 and is led by the World Food Programme (WFP). The cluster's mission is limited to "provid[ing] vital IT and telecoms services to help humanitarian workers carry out operations efficiently and effectively." 43 In 2012, WFP and MasterCard announced a global partnership "that will use digital innovation to help people around the world to break the cycle of hunger and poverty." ${ }_{4}$ In 2013, the Open Humanitarian Alliance came into existence as an initiative whereby organizations and individuals from humanitarian response organizations, academic institutions, government agencies and private sector companies collaborate "to bring the concept of open data into the humanitarian space by addressing the political, technological and capacity issues that currently limit information sharing during disaster." ${ }^{45}$

Critics have often interpreted the evolution of these types of partnerships as neoliberal governance strategies, where "the humanitarian ethos is gradually eroded." ${ }^{46}$ Superficially, humanitarians and the private sector appear to share a set of assumptions about the competence, presence and relevance of the private sector. This was evidenced by the words of an official of the International Telecommunications Union, who noted that private sector organizations are "on the ground" and "often at the heart of the community"; hence, "[c]ooperation between public and private sectors can be ramped up. This will ensure a more effective use of emergency response technologies at the international level." ${ }^{47}$ Nevertheless, to unpack how technology engenders such new settlements, it is necessary to be aware of the heterogeneous character of these partnerships within the humanitarian sector. There is a huge variation in the understanding of what constitutes a public-private partnership and what the appropriate label for the work done actually is. In this context, it is necessary to consider that the ability to call one's own work "humanitarian action" is a public relations strategy, a way of carrying out corporate social responsibility, and a commercial strategy aimed at spearheading access to new markets.

On a deeper level, the disparity is rooted in the fact that affected states, donor states, beneficiaries, international organizations and market actors all view

42 IASC, Emergency Telecom, available at: www.humanitarianinfo.org/iasc/pageloader.aspx?page=contentsubsidi-common-default\&sb=13.

43 ICT Humanitarian Emergency Platform, Emergency Telecommunications Cluster, available at: http:// ictemergency.wfp.org/web/ictepr/emergency-telecommunications-cluster (emphasis added).

44 MasterCard, "MasterCard and the United Nations World Food Programme in Partnership to Deliver 'Digital Food'", Press Release, 13 September 2012, available at: http://newsroom.mastercard.com/pressreleases/mastercard-and-the-united-nations-world-food-programme-in-partnership-to-deliver-digitalfood- $4 /$.

45 See www.nethope.org.

46 Thokozani Xaba, "From Public-Private Partnerships to Private-Public Stick 'Em Ups! NGOism, Neoliberalism, and Social Development in Post-Apartheid South Africa", International Social Work, 27 January 2014 (published online before print).

47 Paul Conneally, "What Technologists and Humanitarians Can Achieve Together", box. 1.1, in IFRC, above note 29, p. 19. 
the state and the overall organization, as well as the objective of humanitarian aid, differently. Hence, attention must be paid to the ways in which ideology and idiosyncrasies shape the templates upon which such agreements are encouraged and entered into, as well as how they play out in practice. According to critics, these partnerships must be carefully managed, as companies are by their very nature mainly interested in "brand, employee motivation and doing more business." 48 The challenge is to flesh out the precise nature of the dilemma. For example, in the case of e-transfers, it has been pertinently observed that:

Crisis-affected persons are not, in this context, customers of the bank with whom the implementing agency has partnered, and are not party to the contracts agreed between the implementing agency and the bank. Banks are not accountable to humanitarian principles and are likely not used to working with individuals with little knowledge of the banking system. ${ }^{49}$

Another dilemma is that victims of disasters are by nature in a vulnerable position, making them potentially easy targets for private companies' interests and easy victims of breaches to their right to privacy, as they may be pressed in emergency situations to accept things they wouldn't have otherwise. Furthermore, critics note that while many of these private companies are powerful global players, even the largest of them-Apple, Google, Microsoft and Facebook-are under the influence of government regulations and national security politics. ${ }^{50}$ This influences their ability and willingness to protect the data of humanitarian organizations. Adding to this, many private sector companies are also military suppliers, and in recent years the humanitarian enterprise has in itself become a huge market for new surveillance and control technologies. ${ }^{51}$ This overlap of the market with both humanitarian and security practices is deeply problematic, as evidenced by the creation of the new Coalition Against Unlawful Surveillance Exports, ${ }^{52}$ which includes Amnesty International, Human Rights Watch and Privacy International.

So far, the proliferation of partnerships has not spurred the development of regulatory standards, and there is a dearth of voluntary guidelines, codes of conduct or principles. There appears to be little consensus on how to structure the dialogue with private sector companies, how to foreground humanitarian principles and

48 See Luk N. van Wassenhove, academic director of INSEAD Humanitarian Research Group, in How Applied Research Can Contribute to Improvements in Future Humanitarian Supply Chains, CONTRIBUTE workshop, BI Norwegian Business School, 2014, available at: www.noreps.no/PageFiles/ 1156/BI,\%20210114,\%20slides.pdf.

49 Leah Campbell, "Cross-Sector Cash Assistance for Syrian Refugees and Host Communities in Lebanon: An IRC Programme", The Cash Learning Partnership, 1 April 2014, available at: www.cashlearning. org/resources/library/410-cross-sector-cash-assistance-for-syrian-refugees-and-host-communities-inlebanon-an-irc-programme.

50 Ronald J. Deibert, Black Code: Inside the Battle for Cyberspace, McClelland \& Stewart, Toronto, 2013.

51 See notably the revelations that the NSA bugged humanitarian organizations: "GCHQ and NSA Targeted Charities, Germans, Israeli PM and EU Chief", The Guardian, 20 December 2013, available at: www. theguardian.com/uk-news/2013/dec/20/gchq-targeted-aid-agencies-german-government-eu-commissioner

52 See the Coalition Against Unlawful Surveillance Exports website, available at: www.globalcause.net. 
transparency, ${ }^{53}$ or how to distinguish actors with an interest in corporate responsibility from those seeing the humanitarian space exclusively as a new market opportunity for their products. Whether or not humanitarian organizations are aware of such risks, they face a tacit and indirect pressure to adopt new technologies for "cost-efficiency" and "risk-avoidance" reasons. For researchers, the problem is also methodological: the lack of standardization and confidentiality agreements will make such partnerships difficult to scrutinize.

\section{Paving the way to new methods for distributing aid}

The notion that "[c]ommunications are an important form of aid, and can be of equal importance to survivors as food, water and shelter", ${ }^{44}$ is a mainstay of the humanitarian technology discourse-and increasingly also of the general humanitarian discourse. According to the World Disasters Report 2013, "[s]elf-organization in a digital world affords opportunities unfeasible in the analogue past. Disaster-affected populations now have greater access to information, and many of their information needs during a crisis can be met by mobile technologies." ${ }^{55}$ In essence, these kinds of statements represent a move to see value-added information as relief in itself. ${ }^{56}$

We suggest that attention must be paid not only to how humanitarian technology impacts on what counts as resources, but also to the distribution of resources, in terms of who gets what, who gets to distribute, where this happens and why. In the following section we consider the latter issue in greater depth by looking at the case of e-transfers, often called "mobile money" or "digital food" in the humanitarian context. Over the last decade, the international development community has invested heavily in the so-called financial inclusion agenda, aiming to make poor people less aid-dependent; this is sometimes labelled "resilience through asset creation." 57 The underlying assumption is that access to financial services such as credit and savings will "create sizeable welfare benefits" as beneficiaries of aid are drawn further into the market economy as customers. ${ }^{58}$ In tandem with humanitarianism's general turn to transparency, accountability and efficiency, the goal of implementing "cost-effective" electronic payment programs is also to help beneficiaries "save money, improve efficiencies and prevent fraud." 59 The belief is that cash can "go where people cannot", and

53 Interview with OCHA official, New York, 11 October 2013.

54 GSMA, "Key Takeaways from the UN Working Group on Emergency Telecommunications", 17 April 2014, available at: www.gsma.com/mobilefordevelopment/key-takeaways-from-the-un-working-groupon-emergency-telecommunications.

55 See IFRC, above note 29, Chapter 3, p. 73.

56 This section builds on K. B. Sandvik, above note 26.

57 The World Food Program, Building resilience through asset creation, November 2013, available at: http:// documents.wfp.org/stellent/groups/public/documents/communications/wfp261744.pdf

58 Daniel Radcliffe and Rodger Voorhies, “A Digital Pathway to Financial Inclusion”, 11 December 2012, available at: http://ssrn.com/abstract=2186926.

59 Tom Groenfeld, "MasterCard Promotes Financial Inclusion with Electronic Payments", Forbes, 9 September 2013, available at: www.forbes.com/fdc/welcome_mjx.shtml. 
provide them with choice. This determinist vision of technology and capital fits with a key attribute of the humanitarian agenda: it is not redistributive, but focuses on helping those in need.

The World Food Programme has taken the lead in this development as a part of its broader strategy to move away from food aid and to improve food security through cash assets. ${ }^{60}$ In a Kenyan pilot project, WFP is working with MasterCard and Equity Bank to implement a "digital food" delivery system whereby recipients are provided with a debit card linked to a bank account that holds their allowance. According to WFP, beneficiaries preferred the "digital food" allowance over food distribution because it provided choice and helped avoid misuse of cash. It was also found to be $15 \%$ cheaper than in-kind food assistance. ${ }^{61}$

Nevertheless, challenges abound for the project, including "an unprepared agent network outside of Port-au-Prince, a lack of mobile network in northern Uganda, limited bank networks and payment infrastructure in remote areas of the Philippines and challenges channelling the cash for the transfers in Kenya."62 In an early phase, WFP Kenya found that network connectivity was not strong enough to process payments under the initially devised solution. Unstable network coverage also presented a challenge: in July 2013, for example, Equity Bank experienced a week of unreliable service due to a crash of the operating system of its data base. ${ }^{63}$ Through the early implementation phase, there were inconsistent and delayed payments (initially, $74 \%$ of the recipients did not receive their payments), resulting in frustrated and confused recipients who sometimes took on short-term credit to cover the shortage. WFP expressed surprise over subsequent "recipient behaviour": when cash did come, the vast majority rushed to the agent to cash out at the same time, because of lack of trust and because the programme only covered the cost of one withdrawal fee per payment cycle. This caused long lines, insufficient agent liquidity, agent frustration and recipient confusion. Recipients also lacked technical and financial literacy, and did not always know their PINs or how to enter them. ${ }^{64}$ Sometimes agents demanded recipients' PINs or pressured recipients to buy goods in their outlets. Finally, many recipients had to travel significant distances to the nearest agents, and security continued to be an issue. ${ }^{65}$ Examples of this kind only point to selected challenges related to the use of technology for the distribution of resources.

60 By 2015, WFP expects almost a third of its assistance to be delivered in the form of cash, vouchers and "digital food" through smart cards and e-vouchers delivered by short text messages.

61 Consultative Group to Assist the Poor (CGAP), World Bank, Cash for Assets: World Food Programme's Exploration of the In-Kind to E-Payments Shift for Food Assistance in Kenya, September 2013, available at: www.cgap.org/sites/default/files/eG2P_Kenya.pdf.

62 Jamie Zimmerman and Kristy Bohling, "E-Payments in Low-Income Settings: Cutting-Edge or High Risk?", CGAP, 12 March 2014, available at: www.cgap.org/blog/e-payments-low-income-settingscutting-edge-or-high-risk.

63 CGAP, above note 61 .

64 L. Campbell, above note 49.

65 CGAP, above note 61 . 
However, they illustrate that technology creates dependencies that, when disrupted, potentially aggravate the crisis situation.

\section{Reorganizing relationships}

By allowing for more remote engagement with crisis situations, humanitarian technology reshapes relationships between individuals and communities in need, as well as between the individuals and professional groups aiming to provide relief. ${ }^{66}$ As discussed above, the notion that the humanitarian space is shrinking as humanitarian workers are facing a more dangerous operative environment is a central preoccupation in the politics of contemporary humanitarianism. In the context of the "war on terror", the attacks against the UN in Iraq, Afghanistan and other locations have engendered a long-term trend towards risk avoidance. At the same time, agencies seek to expand their presence in conflict zones, pursuant to the logic of the political economy of the humanitarian enterprise: it is through their ability to "stay and deliver" 67 that donors perceive humanitarians" added value.

This amalgamation of danger and a higher degree of presence has resulted in an increasing bunkerization of humanitarian actors, involving a progressive withdrawal of many international aid personnel into fortified aid compounds, secure offices and residential complexes, alongside restrictive security and travel protocols. ${ }^{68}$ This relationship between higher risk and endured presence is mediated through humanitarian technology. In areas such as Syria, South Sudan and Somalia, cell phones, social media and big-data analytics play an important role in allowing humanitarian organizations to continue operating. ${ }^{69}$ The expectation is that remote management as a form of "simulating the experience of proximity" 70 will help humanitarians to address the costs to the quality of assistance, as experienced staff withdraws from the field. The web portal DisasterReady.org, for example, offers aid workers the ability to:

Share resources and information and access customized online learning anytime, anywhere in the world. By providing high-quality, accessible training at no cost, the DisasterReady.org Portal allows aid workers to do what they do best: save lives, rebuild communities, and restore hope. ${ }^{71}$

66 This section builds on K. B. Sandvik, above note 26.

67 OCHA, To Stay and Deliver: Good Practice for Humanitarians in Complex Security Environments, OCHA, New York, 28 February 2011, available at: http://reliefweb.int/report/world/stay-and-deliver-goodpractice-humanitarians-complex-security-environments-enar.

68 Sarah Collinson and Mark Duffield, Paradoxes of Presence: Risk Management and Aid Culture in Challenging Environments, HPG, ODI, London, March 2013, available at: www.odi.org.uk/sites/odi.org. uk/files/odi-assets/publications-opinion-files/8428.pdf.

69 Joe Belliveau, "Remote management' in Somalia", Humanitarian Exchange Magazine, No. 56, January 2013, available at: www.odihpn.org/humanitarian-exchange-magazine/issue-56/remote-management-insomalia.

70 S. Collinson and M. Duffield, above note 68.

71 See www.disasterready.org/about. 
According to the critics, something more complicated is happening: Duffield describes remote management as the "distancing tendency" in humanitarian action. He argues that technology is replacing on-the-ground truth, through technological innovation, simulation and visualization premised on an "uncritical technological-determinist vision of simulating the moods, expectations and actions of remote disaster affected populations." 72

At the same time, remote management signifies a "re-allocation of risk" towards local organizations and beneficiaries, whereby technology is not only a management tool but also a vehicle for increased self-reliance as technologies "also enable communities to quickly transform themselves into first responders", access updates about relief operations, give feedback to humanitarian actors and make complaints. Technology plays a central role as "ever-greater powers of selforganization and self-management are being demanded of populations." ${ }^{33}$ In remote management, face-to-face encounters disappear, normalizing a disconnect between aid organizations and their main stakeholders. ${ }^{74}$ Remote technologies may also create a situation where both humanitarians and beneficiaries overestimate the actual degree of beneficiary empowerment and participation engendered through the use of remote management technologies. ${ }^{75}$

Parallel to the retreat of traditional humanitarians, technology is also bringing new actors into remote humanitarian action: we still know little about how these groups engage with humanitarianism and how their work will shape the future of humanitarian action. The more critical information infrastructure there is that can be damaged in a disaster, the more important are the private sector companies owning that infrastructure. They become a "relief provider" by dispatching individual employees to mend cell phone towers and re-establish network access. ${ }^{76}$ The reliance on remote technologies also brings in invisible crowds of technical workers de facto contributing to humanitarian action. Here we borrow an example from Daniel Gilman of OCHA, who observes that a mobile phone application that allows the direct entry and transmission of user registration also brings an application developer, a mobile phone or satellite company, an internet service provider and a data storage company into the relationship, as well as government regulators - all of these being invisible to the beneficiary. ${ }^{77}$

The proliferation of new actors also heightens the risk of duplication of efforts. In the aftermath of the Haiti earthquake there was a proliferation of new sites tracking missing persons, hosted by the The New York Times, CNN and Google, among others. Quickly, it became apparent that these efforts were "redundant and potentially confusing because they separately tried to solve the

72 M. Duffield, above note 7.

73 Ibid.

74 S. Collinson and M. Duffield, above note 68 .

75 K.B. Sandvik, above note 33 .

76 A. Nelson and I. Sigal with D. Zambrano, above note 14.

77 Daniel Gilman, "Humanitarianism in the Age of Cyber-Warfare", presentation, 26 October 2013, Human Security: Humanitarian Perspectives and Responses Conference, Istanbul, 24-27 October 2013. 
same problem, lacked common coding standards and did not share information with other efforts." 78 They also duplicated the International Committee of the Red Cross's (ICRC) traditional efforts to locate missing persons. Similarly, during the Haiti earthquake, Ushahidi, in conjunction with Tufts University in the United States, provided a platform for crowdsourcing via the 4636 SMS short code, and plotted nearly 4,000 distinct events. Confusion ensued when the Thompson Reuters Foundation began using the same short code for public service announcements. ${ }^{79}$

So far, the most attention has been given to the emergence of the remote volunteering and technological communities (V\&TCs) and their practices. Spurred by technical capacity and low barriers to entry, these groups now play an increasingly important role in humanitarian contexts - generating, aggregating, classifying and even analysing data, in parallel to, or sometimes in collaboration with, more established actors and multilateral initiatives. As a starting point, it is important to be aware that digital humanitarians are a heterogeneous group, with different skills, motivations, practices and objectives. So far, most of the scholarly attention has been given to a relatively small group of actors: the Standby Task Force (SBTF), Humanitarian OpenStreetMap Team and Crisis Mappers are three of the most well-known and structured examples of such initiatives, which have enjoyed formalized relationships with traditional humanitarian actors, processing and generating information in the support of humanitarian interventions. As a field, digital humanitarianism is in large part driven by high-profile normentrepreneurs; like any field of practice, digital humanitarianism comes with its own set of controversies and contestations over what has happened and what should happen. Critical inquiry must be broadened to discuss the state of critical debate within the field as such, and to analyse the activities of newer outfits like MicroMappers, exploring not only how approaches to problem definitions and problem-solving shift, but why they shift.

While the participation of this new group of remote humanitarians is frequently described as a "game changer" for humanitarian action, important issues pertaining to the participation of both corporate and volunteer humanitarians remain unaddressed. Crowdsourcing is based on the assumption that the aggregated input of remote participants will produce better knowledge but what exactly does a crowd know about a crisis? Available evaluation reports indicate a mixed picture: the evaluation of the Ushahidi Haiti Project noted "a marked lack of understanding of operational aspects of emergency response" among the volunteers. ${ }^{80}$ As a consequence of this, for example, the SBTF does not engage or communicate with disaster-affected communities "because that responsibility is not one that digital volunteers are equipped to manage." ${ }^{11}$

78 A. Nelson and I. Sigal with D. Zambrano, above note 14.

79 IFRC, above note 29, p. 168.

80 Nathan Morrow et al., Independent Evaluation of the Ushahidi Haiti Project, Development Information Systems International, 8 April 2011, p. 25.

81 Patrick Meier, personal communication on file with authors, July 2014. 
Moreover, as the digital humanitarian community continues to proliferate, there are concerns about the professional identity of new actors in the volunteer and technical communities. Individual volunteers participating in such initiatives are often less equipped than traditional humanitarian actors to deal with the ethical, privacy and security issues surrounding their activities. Having taken technical know-how and a desire to do good as their starting point, V\&TCs may not be familiar with, or care about, key humanitarian principles such as neutrality, impartiality and independence, and may not have enough contextual understanding to effectively assess the impact of their own work in relation to the "do no harm" principle. Nor is it clear to what extent V\&TCs see themselves as engaged in humanitarian action and, therefore, as accountable according to the standards and principles of the humanitarian enterprise. In response, the Digital Humanitarian Network and OCHA have since actively collaborated on preparing guidelines for cooperation between V\&TCs and formal humanitarian organizations, ${ }^{82}$ and codes of conduct have been developed for organizations like the SBTF. ${ }^{83}$ Nevertheless, even though particular situations and challenges can be addressed by codes of conduct and specific training, these examples illustrate more broadly that humanitarian technologies change and will continue to change relationships among people and between people and organizations.

\section{Technologies for humanitarian data collection: new trade-offs and vulnerabilities}

The use of information technology for collecting and processing data in humanitarian settings engenders well-known dilemmas concerning data responsibility (of course, paper-based protection also carries these risks). Yet, the special case of the emergency setting means that these dilemmas must be considered in the light of context-specific trade-offs. In the following section, we outline what a set of individual, organizational and systemic trade-offs might look like.

At the individual level, there is a trade-off between increasing the efficiency of humanitarian action and protecting the privacy of beneficiaries in crises. Generally, protecting the privacy of vulnerable groups and individuals will require the allocation of time and resources in order to conduct risk assessments, to engage and secure informed consent, and to implement informational security protocols with respect to data collection routines and secure data storage. In humanitarian contexts, the imperative to act quickly and decisively may often run

82 Luis Capelo, Natalie Chang and Andrej Verity, "Guidance for Collaborating with Volunteer \& Technical Communities", Digital Humanitarian Network, 2013, available at: http://digitalhumanitarians.com/ collaboration-guidance; Mary E. Milner and Andrej Verity, "Collaborative Innovation in Humanitarian Affairs: Organization and Governance in the Era of Digital Humanitarianism”, Digital Humanitarian Network, 2013, available at: https://app.box.com/s/oq2gdcy466j6bpdvzyxt; Annie P. Waldmann, Andrej Verity and Shadrock Roberts, "Guidance for Collaborating with Formal Humanitarian Organizations", Digital Humanitarian Network, 2013, available at: http://digitalhumanitarians.com/collaboration-with-orgs.

83 SBTF, Code of Conduct, available at: https://docs.google.com/file/d/0B8j8PoWWdddLR V10RW9DVDFJSDQ/edit. For an overview of other codes of conduct, see Digital Humanitarian Network, Code of Conduct, available at: http://digitalhumanitarians.com/content/code-conduct. 
counter to more measured actions intended to mitigate informational risks to privacy and security.

A challenge that complicates the assessment of protection versus efficiency is confusion about different data categories. A prime example of this is the conceptualization of "sensitive data" in the humanitarian context and the definition of corresponding means to protect these data. While generally relating to the personal data of beneficiaries, data may also include information about conflict development and violent outbreaks, as well as information or rumours about planned movements of military or armed groups. Yet, in practice, the unpredictable dynamics of a humanitarian crisis entail that sensitive data are hard to define a priori, with respect to both content and structure: information about who has reported someone else for an offence may suddenly pose a lifeand-death security risk. Additionally, a piece of information may not be sensitive as such, or not even lead to the identification of anyone, but combined and merged with other data through triangulation, it may be the piece that gives sense to a broader set of information and leads to the identification of individuals.

Frequently, however, the problem may be one not of grappling with tradeoffs, but of inadequate planning: Bowcock and Sossouvi note that with respect to e-transfers, risks to beneficiaries include the use of data for purposes other than the intended ones, as well as sharing or sale of data to third parties and the security risk of using mobile phones to convey sensitive data. Even though data are commonly shared with (broadly defined) partners, donors and local authorities, little thought seems to guide data disclosure to third parties. Moreover, exit strategies frequently lack clear plans for data disposal by agencies or the third parties with whom beneficiary data was shared. ${ }^{84}$

On the organizational level, considerations have to be made with regard to financial investments aimed at securing large data volumes vis-à-vis the possibility of spending those funds on delivering aid. New time-saving technologies can spare lives, but may be forgone due to high acquisition costs. Securing data at the operational level also means investment in training staff to be aware of how to collect and secure data in the field and how to transmit data in a secure manner to headquarters and partners. Consent of information suppliers is often presumed when information is provided "actively", either through social media or dedicated reporting platforms, bypassing proper consent procedures.

Furthermore, massive collection of data can turn unwitting humanitarian organizations into intelligence providers, ${ }^{85}$ damaging their credibility and on-theground operationality. ${ }^{86}$ Many of the V\&TCs are not adequately equipped to

84 Haley Bowcock and Kokoevi Sossouvi, "Playing by the Code: Laying Down Some Rules of Engagement for the Use of E-transfers in Humanitarian Response", Human Security: Humanitarian Perspectives and Responses Conference, Istanbul, 24-27 October 2013.

85 Christopher Wilson, "Constructing Consent: Ethical Challenges to Information Innovation in Humanitarianism", Critical Approaches to Humanitarian Technology: Accountability, DecisionMaking and New Actors, academic conference, Norwegian Centre for Humanitarian Studies/Peace Research Institute of Oslo, Oslo, 28-29 November 2013.

86 For controversial perspectives on the crisis mapping effort for Libya, see R. Burns, above note 5; Steve Stottlemyre and Sonia Stottlemyre, "Crisis Mapping Intelligence Information During the Libyan Civil 
understand the risks involved. Government, militia or private cyber groups have capabilities that far exceed the security systems of humanitarian actors in the field as well as those of the V\&TCs, and there are already many examples of entire organizations' data being "owned" by hostile cyber groups, most often without the organization's knowledge. ${ }^{87}$

On the systemic level, there is a drive to merge data silos and "join up" data to create more complete pictures of a crisis in real time. While this is in many ways a positive trend, there is a trade-off between merging organizational data silos to improve coordination and resource efficiency on the one hand, and the risk of more data being accessed by hostile actors on the other. Even in the absence of ill intentions or glaring malpractice, the mere collection of sensitive data creates risk and possible violations of the imperative to do no harm. Increasingly, codes of conduct, handbooks and standards of procedure are filling the regulative void. Crucially, it is not only the type but also the amount of data to be collected that matters: the emphasis on aggregated data is an important element in the drive to knowledge-based humanitarian action. There appears to be a tendency of collecting too much data, according to a "better safe than sorry" logic premised on the practical difficulties of gathering data in crisis settings. The excess data collected again infringes on the privacy of those struggling to survive in crises and disasters. Emergent challenges concerning identity and anonymity also exist at the systemic level: as humanitarian data is aggregated and made public, the chances for re-identification of individuals and groups increase at an unknown rate. This phenomenon, known as the "mosaic effect", is widely recognized but little understood. Having been demonstrated in the private sector, there is little understanding of the dangers that shared anonymous data would create in a humanitarian context, where data may be limited, but the potential damage of re-identification would be extreme. ${ }^{88}$ As pointed out by the 2013 version of the ICRC protection standards, it is possible to gather less data - or data with less detail. ${ }^{89}$

Furthermore, big data and remote sensing capabilities provide an unprecedented opportunity to access contextual information about pending and ongoing humanitarian crises. Many notable initiatives such as the UN Global Pulse project suggest that development of rigorous information

War: An Exploratory Case Study", Policy \& Internet, Vol. 4, No. 3-4, 2012; and Robert Munro, "Crowdsourcing and the Crisis-Affected Community", Information Retrieval, Vol. 16, No. 2, 2013, pp. 210-266.

87 John Scott-Railton, Revolutionary Risks: Cyber Technology and Threats in the 2011 Libyan Revolution, Center on Irregular Warfare and Armed Groups, US Naval War College, Newport RI, 2013; John Scott-Railton and Morgan Marquis-Boire, A Call to Harm: New Malware Attacks Target the Syrian Opposition, The Citizen Lab, University of Toronto, 2013; Carly Nyst, "There's No Good Reason for Spy Agencies to Snoop on Humanitarian Groups", Slate, June 2014, available at: www.slate.com/blogs/ future_tense/2014/05/22/nsa_gchq_spying_on_humanitarian_groups_like_unicef_medecins_du_monde. html.

88 We are grateful to Chris Wilson of the engine room (www.theengineroom.org) for this insight.

89 International Committee of the Red Cross (ICRC), Professional Standards for Protection Work Carried Out by Humanitarian and Human Rights Actors in Armed Conflict and Other Situations of Violence, 2nd ed., ICRC, Geneva, 2013, available at: www.icrc.org/eng/resources/documents/publication/p0999.htm. 
management systems may even lead to feasible mechanisms for forecasting and preventing crises. Nevertheless, there are important issues to be discussed concerning the veracity and validity of data. Multiple data transactions and increased complexity in data structures raise the potential for error in humanitarian data entry and interpretation, and this raises concerns about the accuracy and representativeness of data that is used for policy decisions in highly pressurized situations that demand quick decision-making. Data that are collected or generated through digital or mobile mechanisms will often pose additional challenges, especially regarding verification. Though a significant amount of work is under way to develop software and algorithms for verifying crowdsourced or anonymously provided data, such tools are not yet operational or widely available. Understanding the limitations posed to veracity and validity of humanitarian data is critical in a context where humanitarians struggle to combine evidence-based approaches with effective and timely responses.

\section{Conclusion: what is humanitarian about humanitarian technology?}

In this article, we have attempted to map out a research agenda that identifies humanitarian technology as a field of political contestation. The aim has been to explore what technology does to the humanitarian context, and how the unique characteristics of the emergency context shape the conditions in which technology can operate. By allowing for remote management, humanitarian technology is contributing to a reconceptualization of the humanitarian space. At the same time, the turn to technology has engendered a set of new settlements, most particularly with respect to the emphasis on public-private partnerships. Humanitarian technology also shapes what counts as resources and how resources are distributed. Moreover, by allowing for, and exacerbating, remote management, humanitarian technology reshapes relationships between the "helper" and the "helped". The article has also reflected on how humanitarian data collection, a key element in the drive towards evidence-based humanitarian action, produces new trade-offs and vulnerabilities.

From these different dynamics and discussions emerges a need for reflection on the question: what is humanitarian about humanitarian technology? How does the use of technology for humanitarian practice relate to the moral underpinnings of the humanitarian enterprise, namely the imperative to do no harm? How does it relate to the humanitarian principles of humanity, impartiality and neutrality? We propose that at the heart of a future research agenda for critical humanitarian studies are questions concerning how new technologies introduced in the humanitarian field affect the everyday achievement of these principles and how they alter practices in the field. Such analysis must go beyond any discussion of the costs and benefits of surveillance, information and data collection devices. 
We suggest that new technologies offer new possibilities to better uphold the humanitarian principles, but may come into conflict with the imperative to do no harm if the introduction of these new tools is carried out without further reflection on their impact and a regulating framework. When information is seen both as key to the provision of aid and as aid in itself, bad data collection processes, inaccurate data or the loss of beneficiaries' data can cause significant harm.

\section{The principle of humanity}

It is possible to argue that technologies allow for a better achievement of the principle of humanity in the sense that they allow more people in need to receive assistance. Yet, over the next few years, the combination of the data available to humanitarians, and the ways in which technology allows for a parallel immediacy and remoteness between humanitarians and the field, will impact the way in which empathy is mobilized, and our understanding of a common humanity. Since information technology allows for a remoteness from the scene of crisis and the bunkerization of humanitarians, it potentially strips humanitarian assistance of its respect for the people in need and a contextual understanding of their predicament-both of which are the basis for the humanity principle. The humanity principle more broadly risks being jeopardized if data on people in need are not managed properly and their right to assistance or their security is compromised as a consequence.

\section{The principle of neutrality}

The (simplistic) understanding of technology as an empty vessel waiting to be deployed and filled with meaning could pave the way for the argument that the neutrality principle could be better achieved by technologies, since they may act and decide more neutrally than humans. This article, however, argues that technology is neither neutral nor passively adopted in a crisis. Instead, technologies are used by human beings with different professional and cultural backgrounds, with varying abilities and idiosyncratic preferences. In the same sense, the "neutrality" of any information management system is dependent on the categories and corresponding actions that are entered into it. Furthermore, technology will never allow for perfect neutrality in the sense of freeing humanitarians from the politics of the humanitarian space. The introduction of unknown and novel devices and practices in areas of conflict, where lack of trust and suspicion often prevail, has the potential to feed into already existing conflicts. Thus, attention needs to be paid to how the non-neutrality of communication, mapping and data-gathering technology impinges on the stated objective of humanitarian neutrality. ${ }^{90}$

90 James Der Derian, “The Question of Information Technology in International Relations", Millennium: Journal of International Studies, Vol. 32, No. 3, 2003, pp. 441-456; Maria Gabrielsen Jumbert, "Controlling the Mediterranean Space Through Surveillance: The Politics and Discourse of Surveillance 


\section{The principle of impartiality}

A prevailing argument is that the impartiality principle is potentially better achieved with a digitalized information management system, ensuring that everyone registered receives the aid to which they are entitled. In order to do so, however, it presupposes that anyone in need is registered, and that humanitarians remain aware of populations disconnected by digital divides populations remaining outside of the data collection samples. While humanitarian aid is supposed to be given impartially and based on need alone, relief distribution through technology, such as "mobile money", often requires network coverage, widespread cell phone ownership, sufficient technical and financial literacy among the beneficiary population and the ability of humanitarians to make knowledge-based decisions based on big-data analytics. Technology may enable a better form of humanitarian assistance that doesn't take sides or make distinctions based on race, gender, age or political convictions, and that favours the most urgent cases.

In sum, this article has argued that the deployment of technology for humanitarian action is not only a question of the best match between the most appropriate technology and a specific problem or practice. If that were the case, the successful deployment of technology within the humanitarian field would simply become a matter of specialized, end-user-oriented and purpose-fit innovation - and solutions to humanitarian challenges would likely be technology-driven. Instead, this article has shown that the use of novel technologies brings urgency to all the questions laid out here, whether referring to the politics of humanitarian space, the creation of new settlements, the distribution of resources and the definition of relationships, or the way in which data collection creates new vulnerabilities. Bearing that in mind, we invite the scholarly community and those who implement, develop and invest in humanitarian technologies to carefully evaluate the dynamics that those technologies engender. 